Doi: https://doi.org/10.31578/jebs.v6i2.232

\title{
Teaching the Big Three: Making Sense of Chaucer, Shakespeare, and Milton
}

Edward R. Raupp*

\begin{abstract}
Arguably, the three most important early writers in the English language - indeed, one might say the founders of the language are Geoffrey Chaucer (1343-1400), William Shakespeare (1564-1616), and John Milton (1608-1674). Yet our experience at the higher level of education is that students have had little exposure to the life and times of these writers or of their work. Our study shows that, while some Georgian school leavers have been exposed briefly to a bit of Shakespeare, few have chanced to encounter Chaucer and none to Milton. Moreover, while teaching what we might call "The Big Three" of English language and literature, much the same might be said at the master's level: a bit of Shakespeare, little of Chaucer, and none of Milton. To the extent that students of English as a foreign language encounter any literature at all, they tend to be offered little other than literal translation. "Retell the text." They miss the nuances of the English language as they would encounter them through the greatest of writers. It is, therefore, essential that those who teach any or all of these great writers develop a strategy to fit the needs of the students while meeting the objectives of the course. The key to making sense of Chaucer, Shakespeare, and Milton is to make connections to what students already know, to their own experiences, to make these greatest of all English writers relevant to the lives of the students in ways they can understand.
\end{abstract}

Key words: English literature, Chaucer, Shakespeare, Milton

\section{Introduction}

While teaching English Literature to candidates for the degree of Master of Arts in English Language and Literature, we find that students are mostly accustomed to "retelling the text." And the text is, for the most part, mundane. Their experience in reading anything in English, whether in school or at university, tends to be from workbooks. These "fill-in-the-blank" workbooks may be useful for beginning students, but they are insufficient for more advanced learners. Their exercises appear to be designed to fit a philosophy of foreign language acquisition based on regurgitation at the expense of critical thinking. Coming to classes in Chaucer, Shakespeare, and Milton is a daunting enterprise. In a word, they are unprepared.

\section{Literature review}

There is no shortage of books, papers, and popular articles about Chaucer, Shakespeare, and Milton, about their lives and their works. A leaner collection is how to teach these writers to school pupils and university students. Chaucer is often taught to native English speakers as a foreign language (Clifton, 2018), and there is a good deal of material related to that objective. Shakespeare

\footnotetext{
* Ph.D., Gori State Teaching University, Georgia Corresponding Email: edraupp@gmail.com
} 
is also taught, at all levels, as a drama class. Chaucer is taught as a collection of stories of The Canterbury Tales with scant attention to his other works, such as Troilus and Criseyde and his sonnets. Milton classes are typically confined to Paradise Lost.

In its online article, "Using Literature - An Introduction," BBC (2020) notes the abundance of sources of English literature and argues for its values in language learning:

The purpose of this article is to provide some guidance through the wealth of available materials and support, to provide a platform for sharing ideas and experiences, and to explore some areas that are at the cutting edge of what is, for many teachers, the most powerful instrument in their school bag: literature as a tool for language learning ( p. 1).

Especially useful for teachers of English as a foreign language in the BBC piece is an article by Fitch O'Connell (2020) opposing the arguments against using literature in such classes and making a strong case for using short stories, poems, novels, plays, and song lyrics as ways to "enhance even further the richness of the sensory input that students receive" (p. 3). The BBC article also notes the judgment of Duff and Maley (2007) that "teachers can cope with many of the challenges that literary texts present, if they ask a series of questions to assess the suitability of texts for any particular group of learners" (p. 4). First among these questions is, "Is the subject matter likely to interest this group?" This question goes to the heart of the student-centered content-based approach to teaching and learning English as a foreign language.

\subsection{The literature of Chaucerian pedagogy is minimal. There are two notable exceptions:}

2.1.1 First, Ashton and Sylvester's 2007 Teaching Chaucer, is a set of articles deriving from the New Chaucer Society's colloquium on teaching Chaucer, a series that began in Dublin in 1994 (p. 1). The chapters, including Peggy Knapp's "Chaucer for Fun and Profit" and Steven Kruger's "Series of Linked Assignments," discuss innovative methods of teaching Chaucer at colleges and universities that focus on student-centered, active learning. The strategy aims to enhance both independent research skills and critical thinking. Kathleen Forni (2013) similarly suggests "that Chaucerians engage with popular culture" and "share pedagogical innovations and interests with peers within a public forum" (p. 190). Freeman and Cornwell (1993) also advocate innovation, new ways of reaching students confronting difficult material. A common theme in these innovations suggests establishing interactive communication about Chaucer's life and times and his work. These conversations, described as "Discussions" in the Canvas Learning Management System," might be between teachers and students or among students individually or in groups (Craig, 2013; Wallis, 2020).

2.2.2 Second is Gibaldi's 1980 Approaches to Teaching Chaucer's Canterbury Tales. In his Preface, Gibaldi laments "the decline of the study of both language and history in contemporary American education" (p. ix). The same, however, may not be true in Georgia, and other non-English-speaking countries - where curricula are being updated to include such writers as Chaucer. Ridley (2008) repeats the question of a typical undergraduate, "What has Chaucer to do with me?" (p. xi). One approach to answering that student's question is, as Ridley writes, to explore "three basic characteristics that account for the continuing popularity of Chaucer's poetry": Its visuality in "specific, physical detail"; "an intentional ambiguity"; and "a constant of mammalian motivation" (p. xii). From a teaching perspective, one might see the need to avoid declarations of certainty when reading Chaucer, an approach that may validate the variety of interpretations of a group of students, encouraging them to dig further into the work.

John H. Fisher (2008) goes to the heart of the problem: "What experience, memory, and personality does a twenty-yearold reader from a middle-class family, educated in a public high school in the United States, bring to the reading of poetry intended for an English court audience in the fourteenth century?" (p. 39). Immediately, a teacher of Chaucer - as well as the others in this paper - sees the need for relevance. 
Howard (2008) writes, "The Rubicon of any course about The Canterbury Tales comes after the General Prologue...The Knight's Tale...(p. 58). In teaching The Canterbury Tales, the teacher needs, as Howard asserts, to stress not only the character of the Knight and the details of his story, but the critical importance of the place of the tale in the book: Number One. Chaucer sets the table with a courtly tale befitting the teller of that tale. Provost (2008) calls the Knight's Tale "the 'philosophic cornerstone' of the entire poem" (p. 93). Chaucer then has the Miller dragging the reader away from the idealized life to the real world, the world of the low and decidedly not courtly. This approach of juxtaposition should wake the student to what we have here, to what students themselves encounter in the highs and lows of what they see around them. Carruthers (2008) explicitly goes to relevance, with references to "quality of life" (p. 77). Curran (2008) connects the reader to the "cultural context" of Chaucer but also to our own time.

Several papers enthusiastically advocate the students' immersion of Middle English (e.g. Fisher, 2008. p. 43; Ross, 2008, p. 105). Our experience in teaching Chaucer to non-native English speakers leads us to be less enthusiastic. We require students to read and speak a bit of the original of The Canterbury Tales, and recite a few lines. More than that breaks the theme of relevance.

2.2 Of Shakespeare, even more scholarly literature is available, as well as books and articles proposing teaching and learning methods at all levels. Indeed, Goddard (1951) writes, "How many a book on Shakespeare has been prefaced with a sort of shamefaced apology for 'another book on Shakespeare'" (p. vii). An example of such works at the scholarly level is the connection by Holmes (2019) of Shakespeare to social justice using the NPR podcast, Serial, in which references are made to Romeo and Juliet, "young lovers from different worlds," and Othello, "the villain not a Moor exactly, but a Muslim all the same" (p. 145). Holmes finds that the contemporary story in Serial and Shakespeare's account of villainy and revenge share a "common denominator," and that is "rhetoric: how stories are told and to what ends." Clearly, what Holmes, and others who teach Serial as a supplement to - or even a replacement for - a course in Shakespeare, are looking for is markedly greater student identification with the underlying realities of Shakespeare's tragedies. Teachers who choose to introduce Julius Caesar to their students of political science or history, for example, have a trove of material from which to draw in Raaflaub's recent The Landmark Julius Caesar: The complete works.

At the popular level, Ken Ludwig tells us How to Teach Your Children Shakespeare. Ludwig's formula is to start small, as in "Learning the First Line," and build one layer on top of another, reminding one of what the Egyptians did in building their pyramids. This kind of "mim-mem" (mimic and memorize) is one method of foreign language learning that has both adherents and opponents. Having acknowledged the opposition, we see in award-winning actor John Lithgow's introduction a powerful and personal endorsement of Ludwig's approach: "This book is a teaching primer for parents and a manual for making Shakespeare manageable or fun for kids" (Ludwig, p. xv).

While there are many Shakespeare resources available in physical and virtual libraries around the world, the world's largest Shakespeare collection is at The Folger Shakespeare Library in Washington, DC, in the United States. The Folger is also home to the world's largest collection of First Folios, the book that gave us Shakespeare. Happily, for most people living outside of Washington, DC, much of the Folger's rich collection is available online at folger.edu. One might note that no single volume on understanding Shakespeare compares with that of Harold Bloom (1998). Bloom's coda (pp. 714-735), or some parts of it, should be included in any university Shakespeare class, whether graduate or undergraduate.

More at the popular level - and to be sure, there is much more - students may find in Bill Bryson's Shakespeare (2008) a departure from the heavy commentary in academic journals. Bryson, a travel writer, takes the reader on a journey from his Chapter One, "In Search of William Shakespeare" through the life and times of The Bard and his plays right up to his death in 1616 and beyond, to the "Claimants": "There is," Bryson writes, "an extraordinary - seemingly an insatiable - urge on the part of quite a 
number of people to believe that the plays of William Shakespeare were written by someone other than William Shakespeare. The number of published books suggesting - or more often insisting - as much is estimated now to be well over five thousand ${ }^{\prime \prime \prime}$ (p. 179). This element of Shakespeare studies might appeal to students today, especially to those who are intrigued by murder mysteries so common in 21st century television programs, cinema, and books. We have here an invitation to active learning.

YouTube is surfeit with videos freely available to students showing Shakespeare and his works from scholarly to comical. A video from the National Endowment for the Arts (Bridges, 2004) shows not only professional actors but school pupils, as well, both reciting lines from Shakespeare and sharing how Shakespeare has changed their lives. A discussion of the heartbeat cadence of iambic pentameter and Michael York's recitation of Sonnet 18 are themselves worth spending 21 minutes of class time with the DVD at the beginning of a survey course in Shakespeare.

In the classroom, students may engage Shakespeare's characters by reading, reciting, acting out, and analyzing their soliloquies (Blaisdell, 2006). It is commonly understood that plays, including those of Shakespeare, are meant to be seen on the stage rather than read in a textbook. Students will more easily grasp the rhythm of Shakespeare's lines of iambic pentameter by reading them aloud and listening to the recitations of classmates (Ludwig, 2013). Teachers might use brief forms of Shakespeare's plays, for example, one might use Davidson's version of Romeo and Juliet (2002) for tragedy and A Midsummer Night's Dream (2008) for comedy. Curry and Mercer (2015) provide a comprehensive treatment of the Battle of Agincourt, which can be used as a resource for the study of Shakespeare's historical play, Henry $V$. For business and economics students studying Shakespeare, Farnam (2015) provides a relevant perspective in Shakespeare as an economist.

We find most promising O'Brien's (1993) performance-based approach to teaching Shakespeare, especially Part Two: How to Teach Shakespeare through Performance by Michael Tolaydo. Here we have an approach to teaching tragedy (Romeo and Juliet) and comedy (A Midsummer Night's Dream). We are advised to ask before the performance, "Where does this scene take place?" "Who should come onstage from where?" and other questions aimed at stimulating the students to engage the material.

2.3 As to the literature of Milton, The Oxford Handbook of Milton (McDowell and Smith, 2009), The Cambridge companion to Milton (Danielson, 1999), and Barbara Lewalski's The Life of John Milton (2007) provide important books on Milton's life and times, and Orgel and Goldberg (2008), among others, contain his major works. Dartmouth College in Hanover, New Hampshire (Luxon, 2020) offers the entirety of Milton's extant work, along with a great many references to commentaries, in the College's John Milton Reading Room. It contains the complete poetry and selected prose of John Milton, with introductions, research guides, and a number of hyperlinked third-party annotations. Much of the collection has been digitized and is available online at https://www.dartmouth.edu/ milton /reading_room.

The literature of Miltonian pedagogy, however, is perhaps the leanest of the three writers in our study. Students may identify with, and engage in discussions or debates, the case for reform presented in On the Persistence of Reform: John Milton's "Of Education" and Lessons for the 21st Century. (Raupp, 2020). More generally, Thomas Kranidas's 1986 paper in the Milton Quarterly, offers a relevant insight in "Milton on Teachers and Teaching." We are reminded of Milton's own experiences with teachers and teaching. Milton reflects on the sorry state of teaching and learning in the following passage:

Many of the Gentry, studious men, as I heare...coming to the Universities to store themselves with good and solid learning, and there unfortunately fed with nothing else, but the scragged and thorny lectures of monkish and miserable sophistry, were sent home again with such a scholastical burre in their throats, as hath stopt and hinderd all true and generous philosophy from entring... (Kranidas, p. 26, quoting from Chapter 4 of Milton's Second Book of The Reason of Church-Government Urged against Prelaty) 
To turn this small but densely packed passage from Milton's complex rhetoric into a teachable moment, teachers might have students do a close reading to draw out the meaning and its relevance to their experiences. Teachers might have the students read a few words and ask, What does he mean? The teachers might then give examples of their own experiences - with real or imagined humor. It is likely that the higher the students are on the academic ladder, the more examples they have to share.

As with other writers whose rhetoric, though in modern English, is difficult for today's students to comprehend, there are simple versions of Milton's material. Grant Horner (2007) offers such a lifeline. Of course, the disadvantage of such versions is that the author's elegant writing is rendered more commonplace. One might as well refer to the Cliffs Notes or comic books!

Although there are many books for one teaching Paradise Lost, (e.g., Herman, 2012), one of the most comprehensive collections of Milton's shorter poetry and prose is that of Peter Herman (2007). From teaching the sonnets to Areopagitica to "On the Morning of Christ's Nativity," to the elegiac "Lycidas," and the rest, the chapters are brimming with materials and methodologies. Johnson concludes his 2008 review of Herman's comprehensive treatment of Milton pedagogy with, "I cannot imagine that anyone who teaches [Milton]would not find this an abundantly useful, insightful, and illuminating collection" (p. 539). In that collection, Duran (2007) both asks and answers the questions students - and instructors - frequently ask, especially, the "why?" Her answer is two-fold, and may be used by instructors when introducing the shorter works of Milton: First, "is the simple, honest aesthetic and pleasure Milton's works can provide" p. (47). Second, "in ways that few works can, Milton's texts enable readers to enter into a transhistoric conversation that extends forward and backward and that is at once global and intensely personal" (p. 48).

Varsity Tutors (2021) offers useful lesson plans for Paradise Lost and other poetry. Along with substantial assistance with Paradise Lost, there are sites for links to Milton's poetry, including "Lycidas," "L'Allegro," "Il Penseroso," "On His Blindness," Paradise Regained, Samson Agonistes, and many others. Serious Milton scholars in the Caucasus should consider joining the Milton Society of Georgia and reading and submitting articles to the Caucasus Journal of Milton Studies.

We conclude our examination of Miltonian pedagogy by noting the context of this and the other writers, viz., we are teaching students for whom English is not a first language. Specifically, we are teaching students whose first language is Georgian. We find it useful, as we characterize Paradise Lost as the greatest epic in the English language to juxtapose the poem with the greatest epic in the Georgian language, viz. Shota Rustaveli's Knight in the Panther's Skin (2015), which all of our students have studied in school. It is one way to make connections with our students.

\section{Methodology}

As with any serious investigation, a number and variety of techniques tend to produce a more accurate outcome, one that may be more reliably generalized. This study uses three such techniques: direct observation of student performance in the classroom (that being a virtual classroom); formative evaluation using weekly quizzes and weekly analytical papers; and summative evaluation using midterm and final examinations and analytical presentations. Other methods that we might consider include portfolios, journals, logs and assessments, as well as online assessments with multimedia. We might also consider alternative feedback methods, such as student self-assessment, peer assessment, and a mix of the two. Brown (2013) offers a number of 
suggestions for assessing written skills, including reading, vocabulary, and grammar (pp. 265-330), and oral skills, including listening, note-taking, speaking, pronunciation, and connected speech (pp. 331-383).

\subsection{Methods}

3.1.1 Direct observation. Having taught graduate level courses in Chaucer, Shakespeare, and Milton, we are able to discern difficulties in understanding the material and intervene with positive reinforcement. In place of the traditional "chalk talk," we recommend interactive lessons in which students play a major part in the class using a mix of methods, including Socratic dialogues, formal and informal debates, and student-led discussions of their PowerPoint presentations. In all cases, we model thinking critically, solving problems creatively, communicating effectively, and acting ethically.

3.1.2 Formative evaluation. The informal classroom feedback is an important way to reinforce learning and assess progress, but some kind of formal assessment can play a part in mastering the material, which in the cases of Chaucer, Shakespeare, and Milton may not be intuitive to students for whom English is not a native language. Weekly quizzes can be useful for tasks such as remembering facts, understanding those facts, and applying them to real world situations. In order to build critical and creative skills, we require students to submit one short paper each week, one that uses analysis, evaluation, and creativity.

3.1.3 Summative evaluation. At the outset of each course, students receive detailed syllabi. Final examinations and PowerPoint presentations assess the extent to which students have accomplished the learning outcomes specified in the syllabi. Rubrics are provided for the oral presentation and the essays that are part of the examinations.

3.2. Background information. Chaucer, Shakespeare, and Milton are obligatory for students seeking the master's degree in English Language and Literature. In the bachelor's degree program in English Philology, there is no significant exposure to English literature. That program is largely theoretical, consisting of "retelling the text" and filling in blanks in standard workbooks. There is no emphasis on critical thinking or creative problem solving. It comes as a shock to first-year master's degree candidates when they are required to do more than that with which they have been accustomed. They must be taught the basics of critical analysis.

3.3. Participants. Those from whom we draw our evidence directly for this study include two years of first- and second-year master of arts degree candidates at Gori State Teaching University (GSTU). Nearly all of these students earned a bachelor's degree in English philology, most at GSTU. Before the onset of the coronavirus in early 2020, classes were held in person at the University. Subsequently, classes were held online using Zoom meetings.

3.4. Procedure. Classes in Chaucer were provided to first-year MA students in their first semester and Shakespeare in their second semester. Second-year MA students studied Milton in their first semester, and wrote their master's theses in their second semester. Mid-term and final grades were tabulated and provided to students.

\subsection{Results and analysis}

We estimate that the students were at or about B2, upper intermediate English language level using the CEFR standard (Common European Framework of Reference for Languages). The six reference English levels are widely accepted as the global standard for grading an individual's language proficiency (Tracktest, 2021). The narrative associated with level B2 is, "I can communicate without much difficulty but still make quite a lot of mistakes and misunderstand sometimes." Equally problematical is the students' lack of critical thinking skills. More comprehensively, from Tracktest:

Can understand the main ideas of complex text on both concrete and abstract topics, including technical discussions in his/her field of specialization. Can interact with a degree of fluency and spontaneity that makes regular interaction 
with native speakers quite possible without strain for either party. Can produce clear, detailed text on a wide range of subjects and explain a viewpoint on a topical issue giving the advantages and disadvantages of various options.

Our MA students minimally meet these criteria. Nevertheless, they were admitted to the MA program in Anglistics and required to demonstrate mastery of Chaucer, Shakespeare, and Milton. More importantly, these masters level students have little or no experience in critical thinking in their schooling or in their bachelor's degree program. They need help, and they need that help in their schools and bachelor's degree program in English philology.

\subsection{Discussion}

Graduate students can achieve the objectives of their courses in Chaucer, Shakespeare, and Milton, but only with substantial remedial work in critical thinking. creative problem solving, and effective communication, both orally and in writing.

\section{Conclusion and Recommendations}

Our study reveals that students majoring in English philology at our university are unfamiliar with the life, times, and work of the three greatest writers of English literature. We can reasonably conclude that the situation is about the same in other universities in Georgia. To improve the situation, we recommend professors make the material relevant to the learners' lives.

We further recommend a serious examination of the English language programs in Georgian schools and universities.

Finally, we recommend a thorough analysis of the national examination for master's degree studies and the criteria for admission to the MA program in English language and literature. 


\section{References}

Ashton, G., Sylvester, L. (Eds). (2007). Teaching Chaucer. Palgrave Macmillan.

BBC. (2020). Using literature - An introduction. Retrieved January 4, 2021, from https://www.teachingenglish.org.uk/article/usingliterature-introduction

Blaisdell, B. (2006). Shakespeare's great soliloquies. New York: Dover

Bloom, H. (1998). Shakespeare: The invention of the human. New York: Riverhead Books.

Bridges, L. (2004). Why Shakespeare? Washington, DC: National Endowment of the Arts.

Brown, J. D. (2013). New ways of classroom assessment, revised. TESOL International Association. ED495559

Bryson, B. (2008). Shakespeare. London: Harper Perennial.

Carruthers, M. J. (1980). On making students relevant to Chaucer. In J. Gibaldi (Ed.), Approaches to teaching Chaucer's Canterbury Tales (pp. 76-80). New York: Modern Language Association.

Clifton, N. (2018). Teaching Chaucer as a foreign language. Studies in Medieval and Renaissance Teaching, 25(2), $123-143$.

Craig, G. P. (2013). Evaluating discussion forums for undergraduate and graduate students. Online Classroom, $13(12), 5$.

Curran, T. (1980). The cultural context. In J. Gibaldi (Ed.), Approaches to teaching Chaucer's Canterbury Tales (pp. 97-104). New York: Modern Language Association.

Curry, A., \& Mercer, M. (2015). The Battle of Agincourt. New haven, London: Yale University Press.

Danielson, D. (Ed.). (1999). The Cambridge companion to Milton (2nd edition). Cambridge: Cambridge University Press.

Davidson, D. (Ed.). (2002). Shakespeare for young people: Romeo and Juliet. Fair Oaks, CA: Swan Books.

Davidson, D. (Ed.). (2008). Shakespeare for young people: A midsummer night's dream. Fair Oaks, CA: Swan Books.

Duff, A., \& Maley. (2007). Literature (Resource Books for Teachers). Oxford: Oxford University Press.

Duran, A. (2007). Milton and the undergraduate British literature survey course: Who, where, when, how, and, by all means, why? In P. C. Herman (Ed.), Approaches to teaching Milton's shorter poetry and prose (pp. 47-53). New York: Modern Language Association.

Eklund, H., \& Hyman, W. B. (Eds.), Teaching social justice through Shakespeare. Edinburgh: Edinburgh University Press.

Farnam, H. W. (2015). Shakespeare as an economist. New Haven, CT: Forgotten Books. (Original work published 1913).

Fisher, J. H. (1980). The student as reader of Chaucer. In J. Gibaldi (Ed.), Approaches to teaching Chaucer's Canterbury Tales (pp. 39-45). New York: Modern Language Association.

Forni, K. (2013). Teaching Chaucer and Popular Culture: A Prolegomena. The Chaucer Review, 48(2), $190-204$.

Freeman, D., \& Cornwell, S. (1993). New ways in teacher education. Alexandria, VA: Teachers of English to Speakers of Other Languages.

Gibaldi, J. (Ed.). (1980). Approaches to teaching Chaucer's Canterbury Tales. New York: Modern Language Association. 
Goddard, H. C. (1951). The meaning of Shakespeare (Vol. I). Chicago: Phoenix Books.

Herman, P. C. (2007). Teaching Milton's shorter poetry and prose. New York: MLA.

Herman, P. C. (2012). Approaches to teaching Milton's Paradise Lost (2nd ed.). New York: MLA.

Holmes, R. E. (2019). Teaching Serial with Shakespeare: Using rhetoric to resist. In H. Eklund \& W. B. Hyman (Eds.), Teaching social justice through Shakespeare (pp. 145-154). Edinburgh: Edinburgh University Press.

Horner, G. (2007). John Milton: Classical learning and the progress of virtue. Camp Hill, PA: Classical Academic Press.

Howard, D. H. (1980). The idea of a Chaucer course. In J. Gibaldi (Ed.), Approaches to teaching Chaucer's Canterbury Tales (pp. $57-$ 62). New York: Modern Language Association.

Johnson, W. C. (2008). Review of the book Approaches to Teaching Milton's Shorter Poetry and Prose by Peter C. Herman. Minds and Literature, 42(4), 536-539.

Knapp, P. A. (2007). Chaucer for fun and profit. In G. Ashton \& L. Sylvester (Eds.), Teaching Chaucer (pp. 17-29). Palgrave Macmillan. Kruger, S. F. (2007). A series of linked assignments for the undergraduate course on Chaucer's Canterbury Tales. In G. Ashton \& L. Sylvester (Eds.), Teaching Chaucer (pp. 30-45). Basingstoke, UK: Palgrave Macmillan.

Kranidas, T. (1986). Milton on Teachers and Teaching. Milton Quarterly, 20(1), 26-29. Retrieved January 4, 2021, from http://www.jstor.org/stable/24464619

Lewalski, B. (2007). The life of John Milton. Oxford, UK: Blackwell.

Ludwig, K. (2013). How to teach your children Shakespeare. New York: Broadway Books.

Luxon, T. H. (Ed.). (2020). The John Milton Reading Room. Retrieved January 4, 2021, from http://www.dartmouth.edu/ milton/reading_room/contents/text.shtml

McDowell, N., \& Smith, N. (Eds.). (2009). The Oxford handbook of Milton. Oxford: Oxford University Press.

O’Brien, P. (Ed.). (1993). Shakespeare set free. New York: Washington Square Press.

O'Connell, F. (2020). Get lit up: Literature as a teacher's best friend. Retrieved January 4, 2021, from https://www.teachingenglish.org.uk/article/get-lit-literature-a-teachers-best-friend

Orgel, S.. \& Goldberg, J. (Eds.). (2008). John Milton: The major works. Oxford: Oxford University Press.

Provost, W. (1980). The Boethian unity of the Tales. In J. Gibaldi (Ed.), Approaches to teaching Chaucer's Canterbury Tales (pp. 8996). New York: Modern Language Association.

Raaflaub, K. A. (2017). The Landmark Julius Caesar: The complete works. New York: Anchor Books.

Raupp, E. R. (2020). On the persistence of reform: John Milton's "Of education" and lessons for the 21st century. Gori, Georgia: Blue Impala Press.

Ridley, F. H. (1980). The challenge of teaching The Canterbury Tales. In J. Gibaldi (Ed.), Approaches to teaching Chaucer's Canterbury Tales (pp. xi-xvi). New York: Modern Language Association.

Ross, T. W. (1980). An approach to teaching Chaucer's language In J. Gibaldi (Ed.), Approaches to teaching Chaucer's Canterbury Tales (pp. 105-109). New York: Modern Language Association. 
Rustaveli, S. (2015) The knight in the panther's skin (L. Coffin, Trans.). (Original work published c. 1180-1205.). Tbilisi.

Tracktest. (2021). English language levels. Retrieved January 6, 2021, from https://tracktest.eu/english-levels-cefr/

Varsity Tutors. (2021). John Milton: Lesson plans for Paradise Lost and other poetry. Retrieved January 4, 2021, from https://www.varsitytutors.com/englishteacher/milton

Wallis, L. (2020). Designing effective online discussions. Retrieved January 5, 2020, from https://sites.udel.edu/canvas/2019/11 /designing-effective-online-discussions/ 